per cent. According to Australia, the draft deal with France is in accord with policy; but according to French statements it offers no restrictions on reprocessing.

French industry minister André Giraud said recently that "we have no intention of using a single gramme of Australian uranium for our military programme" but, challenged on safeguards, said "we can say exactly where our power plants are and how Australian uranium will be used".

Hoping that such statements will satisfy the Australians, Euratom negotiators expect to tie up an accord soon, thus clearing the tables for Canada. Euratom fears Canada most; the US position is too uncertain to consider yet.

Canada - which already supplies 50 per cent of Britain's uranium (the rest comes from Namibia) - has the experience of India's 1974 nuclear test, which used Canadian uranium, to keep her resolution firm. The Indian test raised a storm of public protest; and although nonproliferation is no longer an election issue, it could become one if a similar incident occurred with Canadian involvement. And then uranium export might be halted. Thus, Canadian officials argue, it is in the interests of security of supply that Canada requires clear controls over its uranium.

Canada's position is ostensibly the same as Australia's - requiring prior consent for reprocessing, re-transfer and high enrichment. But, say Euratom states, such an arrangement would interfere with national sovereignty, complicate fuel management and give Canada unfair advance warning of impending international commercial deals. Canada, after all, with its fuel-efficient Candu reactors and heavy-water plants, is in the nuclear business as a whole, and not just in uranium exporting.

In the end, everything depends on exactly what is meant by "prior consent". Euratom could be expected to object strongly if it means that each sensitive step in the fuel cycle must first be cleared with Canada: for since fuel streams are inevitably mixed when fuel elements are fabricated and fuel enriched or reprocessed, any reporting of movements to Canada would involve reporting - and clearing - all steps in the cycle. France has stated openly that it would accept no restrictions.

On the other hand, Canada has indicated that it is prepared to interpret prior consent "more broadly". For example, Canada might accept an agreement which stated that its uranium was to be used only for energy, and specified the facilities at which the uranium was to be reprocessed. Canadian experts would still have to be satisfied that Euratom's uranium bookkeeping was effective, and that Canadian uranium could be "tracked" through the system.

And Euratom need be in no doubt about the firmness of Canada's commitment. "We stopped all uranium shipments in
1977 and we can do it again" said a Canadian nuclear official last week. Canada has already cancelled deals with India, Pakistan, and recently Switzerland - which objected to "prior consent". To cancel arrangements with Euratom would be more expensive (the UK needs contracts for another 2,000 tonnes of uranium per year by 1990 , and France another 8,000 tonnes worth some $\$ 500$ million dollars a year) but that appears not to frighten anyone in Canadian government. It does, however, frighten Europe. Robert Walgate

\section{Swedish guidelines}

\section{Cloning committees}

\section{Stockholm}

The regulation of hybrid-DNA research in Sweden is in a mess. Delegates to a recent microbiological conference at Umeå bemoaned the bureaucratic confusion foisted on them by a new regulatory system; and one firm has given up and is moving its activities abroad.

Since 1 January this year, any researcher wanting to work with hybrid DNA has been legally obliged to apply for permission under two existing laws: the Occupational Health and Safety Act (Arbetsmiljolagen) and the Law on the Protection of the Environment (Miljösyddslagen). The bodies that deal with the applications are the National Board of Occupational Safety and Health (NBOSH: Arbetarskyddsstyrelsen) and the Franchise Board for Environmental Protection (FBEP: Koncessionsnämnden törmiljöskydd), respectively. Both bodies are served by a Recombinant DNA Advisory Committee, set up in January under NBOSH. The committee's main task is risk classification. It has 17 members excluding its chairman (the directorgeneral of $\mathrm{NBOSH}$ ) and vice-chairman: four scientists, four members of parliament, five delegates from relevant authorities (National Board of Health and Welfare, Natural Science Research Council, etc.), three trades union representatives and one representative of industry and employers.

Both NBOSH and FBEP refer applications to the committee, which in turn passes them on to its working group on risk classification. If the application came from NBOSH, the working group classifies it and decides whether or not it is for new research (under the Occupational Health and Safety Act, only applications for new research have to be approved). The working group then makes its recommendation to the committee, which passes it on to NBOSH. The trouble with this is that nobody is quite sure what "new" research is. "It is difficult to interpret the meaning of this law", says Gustaf Brunius, who is in charge of DNA questions at NBOSH. "But $E$. coli $\mathrm{K} 12$ is a system that has been very thoroughly investigated, and if an application involves this system it is considered unnecessary to get permission for it unless the DNA sequences for toxins."

The procedure is even more complicated when the application comes from FBEP. FBEP sends the application not only to the committee, but also to 14 other bodies (including local government and health authorities and the Environment Protection Board), and asks for their comments. When all of them have replied - which takes months - FBEP holds a public meeting at which the application is publicly made and the various bodies which wish to comment publicly do so. FBEP then writes a judgement.

University researchers say they have not received any information about this system, and that they do not know how to apply. In practice, they are continuing their research without applying for permission at all, which technically makes criminals of them all. Only one firm has so far applied, and it is holding up its experience as an example of bureaucratic ineptitude. KabiGen which, in conjunction with Genentech Inc., owns the world rights for the production of human growth hormone, had applied for and been given permission to go ahead with developmental work under the old voluntary regulation system. When the new system was brought in, the firm made another application to use hybrid-DNA techniques to produce genes for human growth hormone, somatomedin B and human secretin. Six months later, permission was granted (in volumes of not more than 10 litres); but NBOSH specified P1 conditions, whereas FBEP specified $P 3$. FBEP evidently did not take into account the revision in the National Institute of Health guidelines which occurred while it was considering the application. So KabiGen put in a new application to FBEP for permission to do the same work in $\mathrm{Pl}$ conditions. No decision has yet been made. The firm also applied again to NBOSH for a more general permission to do developmental work, and no decision has been made on that either. "We can do 10 litres here, but we want to do 400 litres", says KabiGen's research director, Dr Bertil Åberg. "It would take too long to get permission for that, and we'd lose too much money. We'll do it in England instead".

Some delegates to the i mea coni rence, which was organized by the Swedish Microbiological Association (universities) and the Foundation for Biotechnical Research (industry), suggested that the researchers themselves should take some of the blame for the present chaos. "There must be experts on the Recombinant DNA Advisory Committee, but they need not be in the majority", said Staffan Normark, Professor of Microbiology at Umeå University. "But everyone taking part in the committee's decisions must know what the research is about. We in the field haven't told them; and perhaps we should."

Wendy Barnaby 